\title{
EFFECTS OF SUPPLEMENTED DIETS ON THE GROWTH PERFORMANCE AND NUTRIENT CONTENTS OF GULSHA TENGRA, MYSTUS CAVASIUS
}

\author{
Kaniz Fatema, Md. Farukul Islam, Nahid Sultana ${ }^{1}$ and Badhan Saha ${ }^{2}$ \\ Department of Fisheries, University of Dhaka, Dhaka-1000, Bangladesh
}

\begin{abstract}
To evaluate the effects of two diets on the growth performance and nutrient contents of gulsha, Mystus cavasius was conducted. Growth performance of gulsha was found maximum in rice bran and spirulina feed (treatment T1) and the lowest was observed in commercial feed (treatment T2). Specific growth rate of gulsha was higher in treatment T1 than treatment T2. Treatment T1 had the best proximate composition (moisture $77.28 \%$, ash $3.45 \%$, lipid $4.31 \%$ and protein content $15.05 \%$ ) and nutrient contents (calcium $115.6 \mathrm{mg} / 100 \mathrm{~g}$, phosphorous $166.7 \mathrm{mg} / 100 \mathrm{~g}$, potassium $207.23 \mathrm{mg} / 100 \mathrm{~g}$, magnesium $25.97 \mathrm{mg} / 100 \mathrm{~g}$, iron $1.85 \mathrm{mg} / 100 \mathrm{~g}$ and manganese $0.23 \mathrm{mg} / 100 \mathrm{~g}$ ). Therefore, it was found to be better option to produce healthy fish for human consumption.
\end{abstract}

Key words: growth performance, nutrient contents, gulsha fish

\section{INTRODUCTION}

Mystus cavasius, locally known as 'Gulsha Tengra' or 'Kabashi Tengra' is one of the important silurid catfish and was once available in rivers, oxbow lakes, floodplains, swamps and canals throughout Bangladesh, India, Burma, Sri Lanka, Nepal and Pakistan (Rahman 2005). It is a favorite fish to the consumers because of its delicious taste, and therefore, has a great demand, fetching high price in the market. This fish withstands harsh environmental conditions, such as low dissolved oxygen concentration, wide range of temperature fluctuations and other poor water conditions. This species is a carnivore, feeding mainly on insect larvae, small fish, crustaceans and debris (Akhteruzzaman et al. 1991).

In recent years, the natural habitats and breeding grounds of this silurid catfish have been severely degraded as a result of environmental perturbations and man-induced hazards in the aquatic ecosystems. These are: destructive fishing practices, physical reduction in water bodies, siltation, application of pesticides in rice cultivation and release of chemical effluents from industrial plants together with hydrological changes caused by construction of numerous flood control structures. These factors have created a serious problem to their genetic resources and thus the fish became gradually endangered (Akhteruzzaman et al. 1991, Kohinoor et al. 2009, Rahman et al. 2013).

*Author of correspondence: <f.kaniz@yahoo.com>. 1Zoology Section, Biological Research Division, BCSIR Laboratories, Dhaka-1205, Bangladesh. ${ }^{2}$ Soil and Environmental Section, Biological Research Division, BCSIR Laboratories, Dhaka-1205, Bangladesh.

(C) 2017 Zoological Society of Bangladesh DOI: http://dx.doi.org/10.3329/bjz.v45i1.34195 
In spite of having large fisheries resources, Bangladesh is facing an acute malnutrition problem due to the shortage of animal protein supply in the diet. Among various production inputs, the choice of fast growing species with desirable aquaculture traits is a pre-requisite for augmenting fish production in culture-based fisheries. Hossain et al. (1998) obtained a production of $3,125 \mathrm{~kg} /$ ha from polyculture of gulsha (Mystus cavasius) in earthen ponds.

Fish growth at different stages is largely governed by the kind of feeding, feeding frequency, feed intake and its ability to absorb the nutrient. In fish culture, to obtain a balance between rapid fish growth and optimum use of the supplied feed is a major concern. In addition, feeding frequency is an important factor for the survival and growth of fish at the early stage (Hung et al. 2001). Knowledge of the nutrient composition of important foods is an invaluable tool in understanding the links between food production, nutrient intakes, and in devising policies and programmes such as development of improved production technologies, to ensure that food supply optimally fulfils population nutrient requirements.

Considering all those prospects of demand, gulsha was selected to conduct this research study. Many workers (Akhteruzzaman et al.1991, Kohinoor et al. 1997, Hossain et al. 1998) have worked on the growth performance and nutrient contents of gulsha collected from various sources all over the world and determined the growth performance and nutrient profile of gulsha. But no study was conducted to observe the growth performance and nutrient contents of gangetic mystus by culture with different supplemented diets. Therefore, the present study was conducted to find out the growth performance by using two types of feed and to compare the growth and nutrient composition of Mystus cavasius reared in different tanks.

\section{MATERIAL AND METHODS}

The experiment was undertaken in four small concrete tanks at Zoology Section, Biological Research Division, Bangladesh Council of Scientific and Industrial Research (BCSIR). Two feeds were used in this experiment to determine their effects on growth performance and nutrient contents of gulsha. Two tanks were used for each treatment. Fry of gulsha were collected from Adorsho Hatchery, Treshal, Mymenshing and transported in oxygenated bags with water.

Experimental design: Four small concrete tanks of $10.00 \times 6.00 \times 2.25$ feet were used in experimental system. Each tank was filled in with 650 litre tap water. Each tank was stocked with 265 fingerlings. After transport, the fry were acclimatized for sometimes in clean water. Then fingerlings were released slowly 
into the tank. No feed was given on first day. From the second day of stocking, feed was given to the tank at a rate of $10 \%$ of body weight of the fish. Feed quantity was decreased in every subsequent month by 8,7 and $6 \%$, respectively. In Treatment 1, rice bran (collected from local market; used directly on the basis of body weight of fish and used twice in a day and spirulina feed (live spirulina cultured at BCSIR, and from that about 3.0 litres was applied each month two times at 15 days interval) were used while commercial feed was used in Treatment 2 .

Physico-chemical parameters: Physico-chemical parameters were measured at every 7 days interval. Water temperature $\left({ }^{\circ} \mathrm{C}\right)$ from each tank was measured by using ordinary thermometer. Dissolved oxygen concentration was measured by a dissolved oxygen meter (Model Oxi 3150i, Germany). pH was measured by pH meter (Jenway, Model 3020, United Kingdom).

Growth parameters: Growth of the fish samples were measured after 30 days interval. Lengths of the fingerlings were measured with measuring scale and weight with weighing balance. Twenty samples were measured randomly at a time. After recording length and weight, fingerlings were slowly released into the labeled tank water. Feed were supplied as per experimental design. The tank was also cleaned every month. Growth of the fingerlings was measured consequently four times at the interval of 30 days. Experiment was continued up to 9 months (culture 5 months and 4 months analysis). The following parameters were used to evaluate the growth and measured by using the formulas of Castell and Tiews (1980):

Survival rate $(\%)=\frac{\text { No. of actual fish survived }}{\text { No. of actual fish stocked }} \times 100$
Average daily gain $\left(\mathrm{ADG}, \mathrm{g} /\right.$ day) $=\frac{\text { (Mean final fish weight } \text { Mean initial fish weight) }}{\text { Time (T2 - T1) }}$

where, $\mathrm{T} 2=$ Final time, $\mathrm{T} 1=$ Initial time

Specific growth rate $(\mathrm{SGR}, \%)=\frac{(\operatorname{In} W \mathbf{T}-\ln \mathbf{W} \mathbf{)}}{\mathbf{T} \mathbf{t}} \times 100$

where, In Wt $=$ Natural log of weight at time $\mathrm{T}$, In W1 $=$ Natural log of initial weight, $\mathrm{T}=$ Final time, $\mathrm{t}=$ Initial time.

Condition factor $(\mathrm{K}, \%)=\left(\mathrm{W} / \mathrm{L}^{3}\right) \times 100$

where, $\mathrm{K}=$ Condition factor, $\mathrm{W}=$ body weight in grams, $\mathrm{L}=$ body length in centimeter

Feed (g)consumed by the fish

Feed conversion ratio $(F C R)=\overline{\text { Weight }(g) \text { gain of the fish }(\mathrm{W} 2-\mathrm{W1})}$

where, $\mathrm{W} 2$ = Final weight, $\mathrm{W} 1=$ Initial weight. 
Biochemical analysis: Moisture, ash, lipid, protein was determined according to the protocol described by Association of Official Analytical Chemists (AOAC 1995).

Fish sample preparation for minerals analysis: Four fish samples were collected from the four experimental tanks and kept in sealed polypropylene bags at room temperature. The fish was then meshed and $5 \mathrm{gm}$ of meshed wet sample was taken into an oven; dried at $60^{\circ} \mathrm{C}$ for $48 \mathrm{hrs}$ and then it was grinded. One gm of dry sample was taken in a beaker and $10 \mathrm{ml}$ of nitric acid was mixed with the sample. The mixer was then put into fume chamber and digested at $80^{\circ} \mathrm{C}$ until the solution became clear and added $5 \mathrm{ml}$ perchloric acid. Then the solution was diluted to $50 \mathrm{ml}$ deionized water and was filtered and collected into clean and sterilized plastic bottles for further analysis (Huq and Alam 2005).

Laboratory assay: $\mathrm{Ca}, \mathrm{Mg}, \mathrm{Fe}, \mathrm{Mn}$ and $\mathrm{Cu}$ contents of the fish samples were analyzed by using Atomic Absorption Spectrometer (Model No.: AA-7000, Shimadzu, Japan). The phosphorus in the sample was measured with UV/VIS Spectrophotometry. The Potassium in the sample was measured with Flame photometer.

\section{RESULTS AND DISCUSSION}

Survival rate (\%): Fig. 1 shows the survival rate of gulsha fish cultured for four months with two different treatments.

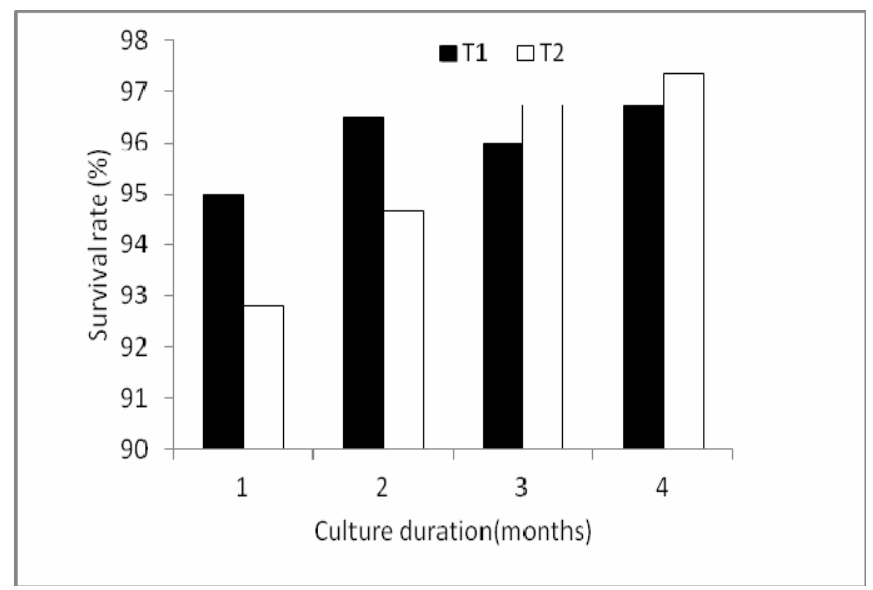

Fig. 1. Survival rate of gulsha fish cultured for four months with two different treatments.

After one month, survival rate was found higher in treatment 1 (95\%) than treatment $2(92.8 \%)$. The higher survival rate was observed in treatment T2 $(97.35 \%)$ and the lower in treatment $\mathrm{T} 1$ (96.7\%) after four months rearing period. Survival rate depends on several climatic factors including temperature, 
salinity, DO, light intensity, water current and other various factors such as availability of feed and stocking density etc (Nikolsky ,1963). Result shows that early stage of gulsha culture rice bran and spirulina are more favorable to fingerlings than commercial feed.

Average daily gain $(A D G)$ : The highest average daily gain $(\mathrm{ADG}=0.527)$ of gulsha fingerling was observed in treatment $\mathrm{T} 1$ at fourth month and the lowest value $(\mathrm{ADG}=0.001)$ in Treatment $\mathrm{T} 2$ at third month (Fig. 2).

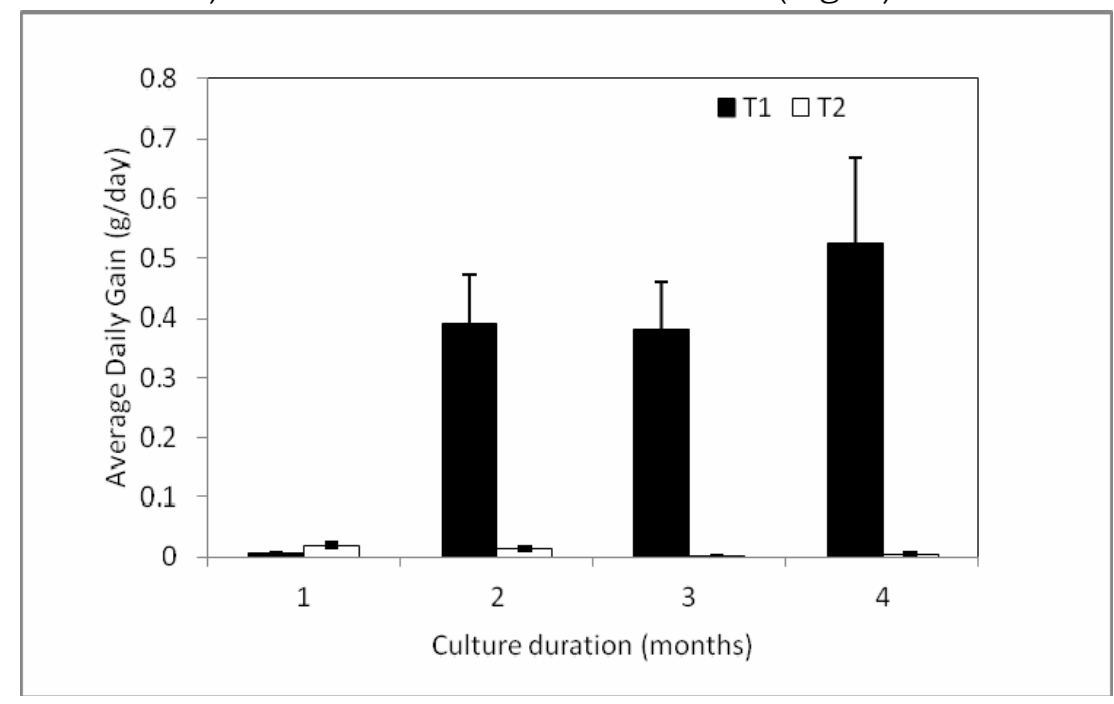

Fig. 2. Average daily gain (Mean $\pm \mathrm{SEM}$ ) of four month's rearing with two different treatments.

Increased ADG of the fish suggested that the fish were able to regulate osmotic pressure of the body fluid; this was in agreement with suggestions of Nikolsky (1963), the more the osmo-regulatory adaptation, lesser the difference between the compositions and pressures of the internal fluid of the organism and its external environment. Moreover, ADG value relies on size of fish, sex, age and physiological condition.

Specific growth rate $(S G R)$ : The highest specific growth rate $(S G R=3.396)$ of gulsha fingerling was observed in treatment T2 at first month. During the three months of rearing period the SGR was also observed lowest $(\mathrm{SGR}=0.160)$ in treatment T2 (Fig. 3).

The maximum value of SGR found at T2 at first month during rearing period of gulsha fingerlings while the minimum value was found at T1 at third month. This finding is in conformity with Medawars (1945) fifth law "the specific growth rate declines more and more slowly as the organism increases in age" at the various conditions. Minot (1990) reported that the specific growth rate is the 
highest for most of the animals early in life and then it typically decreases with increasing age, becoming zero in some animals.

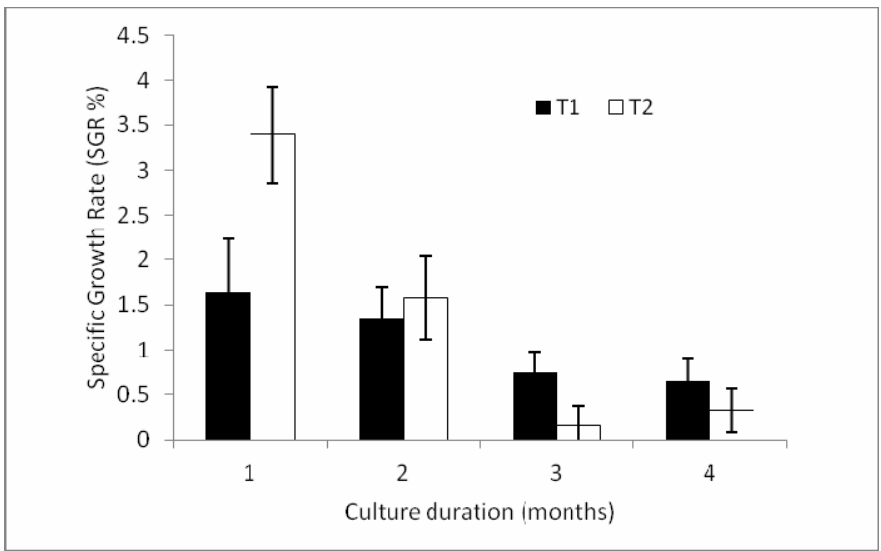

Fig. 3. Specific growth rate (\%), (Mean \pm SEM) of four month's rearing with two different treatments.

Condition factor $(\mathrm{K})$ : Condition factor $(\mathrm{K})$ of gulsha fingerlings was the highest $(\mathrm{K}=0.938)$ in treatment $\mathrm{T} 1$ at fourth month and the lowest $(\mathrm{K}=0.606)$ value was found in treatment T2 at the beginning of the experiment (Fig. 4).

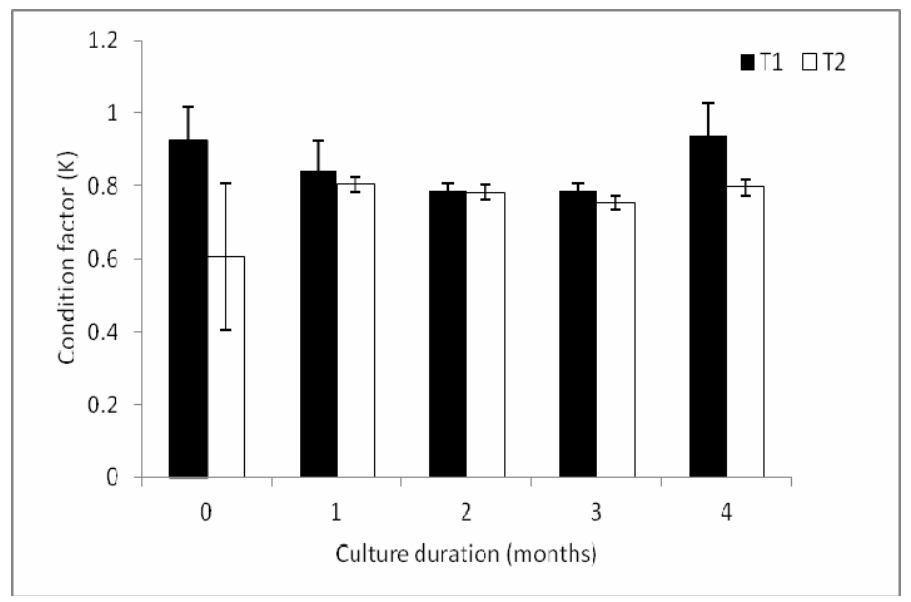

Fig. 4. Condition factor $(\mathrm{K})$, (Mean $\pm \mathrm{SEM}$ ) of gulsha fish culture for four months with two treatments.

Condition factor $(\mathrm{K})$ showed the less variation and good performance at $\mathrm{T}$. In $\mathrm{T} 1$ the $\mathrm{K}$ value $(\mathrm{K}=0.9381)$ was higher than treatment T2. Berra (1981) observed K value nearly 1.0 in Anabas testudineus. Rahman et al. (1997) studied on the survival and growth of cat fish with selected supplemental feeds and found that the values of condition factor varied from $0.51-0.80$. 
Feed conversion ratio (FCR): The highest value $(\mathrm{FCR}=0.964 \pm 0.217)$ was observed in treatment $\mathrm{T} 2$ at third month.

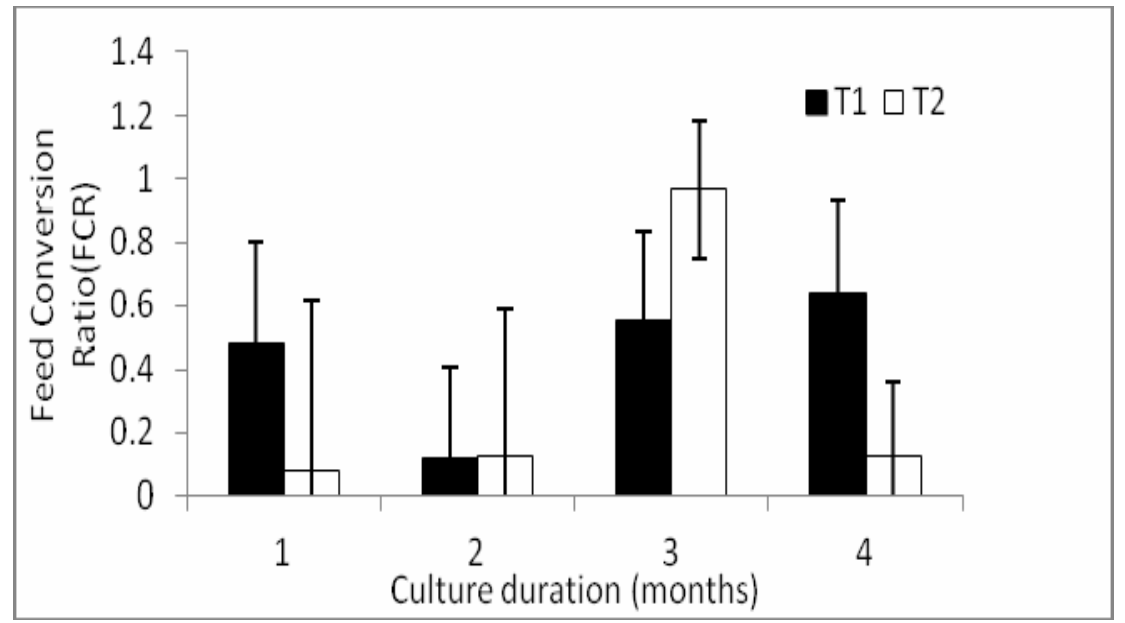

Fig. 5. Feed conversion ratio (Mean \pm SEM) for four months rearing with two different treatments.

During the rearing period the lowest value was observed $(\mathrm{FCR}=0.75 \pm$ 0.539)) in Treatment T2 at first month (Fig. 5). In this study, feed conversion ratio (FCR) of gulsha fingerlings was different at the two treatments. Moreover, the highest value of FCR was found at treatment T2 and the lowest one at T1. The efficiency of FCR depends on many factors but the best response is probably strongly related to optimize the environment. The growth rate, feed intake and feed conversion efficiency was found the highest values at treatment T2.

Proximate analysis: Table 1 shows the proximate composition (moisture, ash, lipid and protein) of cultured gulsha fish at fourth month.

Table 1. Proximate composition (Mean \pm SEM) of gulsha fish cultured at fourth months with two different treatments

\begin{tabular}{lll}
\hline \multicolumn{1}{c}{ Proximate composition } & Treatment T1 & Treatment T2 \\
\hline Moisture & $77.28 \pm 0.3036$ & $78.69 \pm 0.179$ \\
Ash & $3.45 \pm 0.128$ & $3.15 \pm 0.063$ \\
Lipid & $4.17 \pm 0.265$ & $3.03 \pm 0.180$ \\
Protein & $15.05 \pm 0.013$ & $14.85 \pm 0.153$ \\
\hline
\end{tabular}

Moisture content: Percentage of moisture in gulsha fish with different kinds of feeds depicted in Table 1. It was observed that moisture content in gulsha fingerlings fed with commercial feed was higher $78.69 \%$ at the treatment T2. 
The moisture content of fingerlings fed with rice bran and spirulina was $77.28 \%$. Stansby (1963) reported that moisture content for fresh water fish was to be in the range of $72.1-83.6 \%$, with a mean of $77.64 \%$ and this study also observed similar results. Rubbi et al. (1987) investigated that the moisture content for 27 species of fresh water fish, where moisture content was found to be in the range of $72.18-83.65 \%$ which is also similar to the present study. Desrosier (1977) reported that general fish contains 70 - 80\% moisture. Moisture content of fish depends on some factors such as seasons, sex, age etc. Thus, moisture content in present study is in a good agreement with the values reported in all these previous studies.

Ash content: Table 1 shows the ash content, (Mean \pm SEM) in gulsha fish cultured for four months with two different treatments. The higher ash content $(3.45 \%)$ was found in fish samples fed with the rice bran and spirulina. Whereas, the lower ash content (3.15\%) was found in fish samples fed by commercial feed. Ash content was found the highest at T1 and the lowest in T2. Similar observation was made in Banu et al. (1991).

Lipid content: The percentage of lipid in gulsha fingerlings fed with different feeds are shown (Table 1). Lipid content was found to be in the range of (4.61$2.09 \%$ ). The higher percentage was found in fish fed with rice bran and spirulina (4.31) while the lower percentage was observed in fish fed with commercial feed (2.17). Rubbi et al. (1987) reported that the lipid content of 27 species of freshwater fish in Bangladesh and varied from $0.89-15.11 \%$.

Protein content: Percentage of crude protein for gulsha fish is shown in Table 1. Protein content was found to be in the range of (14.85-15.05\%). The higher protein content was found in T1 $(15.05 \%)$, while the lower in T2 $(14.85 \%)$. In a previous study (Dresosier 1977), protein content in fish was reported to be 13 $20 \%$. Protein content is subjected to the variation of factors such as size, sex, habitat, physiological condition and also season.

Physicochemical parameters: Physicochemical parameters are important to enhance the growth of fish in aquaculture. In this investigation the average temperature of water was recorded $\left(28.75 \pm 0.104^{\circ} \mathrm{C}\right)$, the average of dissolved oxygen was $(8.15 \pm .147 \mathrm{mg} / \mathrm{l})$, the range of $\mathrm{pH}$ was $(8.23 \pm 0.0574)$. Rahman et al. (2005) observed acceptable temperature $\left(29.2-31.8^{\circ} \mathrm{C}\right)$ in the experimental ponds for nursing of gulsha fingerlings which is closer to the present study observations.

Minerals (Calcium, potassium phosphorus, Iron, Manganese and magnesium) analysis of fish sample: The higher value of calcium (115.6 mg/100 g of fish) was found in the fingerlings fed with rice bran and spirulina in T1 while the lower 
value $(112.32 \mathrm{mg} / 100 \mathrm{~g}$ of fish) was observed in those fed with commercial feed in T2 (Table 2.).

Table 2. Mineral contents (mg/100g) in gulsha fish cultured for fourth month with two different treatments

\begin{tabular}{ccc}
\hline Minerals & Treatment 1 & Treatment 2 \\
\hline $\mathrm{Ca}$ & 115.6 & 112.32 \\
$\mathrm{~K}$ & 207.23 & 205.37 \\
$\mathrm{P}$ & 166.7 & 161.3 \\
$\mathrm{Fe}$ & 1.85 & 1.78 \\
$\mathrm{Mn}$ & 0.18 & 0.23 \\
$\mathrm{Mg}$ & 25.97 & 24.15 \\
\hline
\end{tabular}

The higher phosphorus content (166.7 mg/100 $\mathrm{g}$ of fish) was found in fingerlings fed with rice bran and spirulina while the fingerlings fed with commercial feed contained the lower phosphorus (161.3 mg/100 g of fish).

The higher potassium content $(207.23 \mathrm{mg} / 100 \mathrm{~g}$ of fish) was found in fingerlings fed with rice bran and spirulina while the fingerlings fed with commercial feed contain the lower potassium $(205.37 \mathrm{mg} / 100 \mathrm{~g}$ of fish).

The higher magnesium (25.97 mg/100 $\mathrm{g}$ of fish) was found in the fingerlings fed with rice bran and spirulina while the lower magnesium $(24.15 \mathrm{mg} / 100 \mathrm{~g}$ of fish) was observed in those fed with commercial feed (Table 2).

The higher iron content $(1.85 \mathrm{mg} / 100 \mathrm{~g}$ of fish) was found in fingerlings fed with commercial feed while the fingerlings fed with rice bran and spirulina contain the lower percentage $(1.78 \mathrm{mg} / 100 \mathrm{~g}$ of fish). The higher amount $(0.23 \mathrm{mg} / 100 \mathrm{~g}$ of fish) of manganese content was found in fingerlings fed with commercial feed while the fingerlings fed with rice bran and spirulina contain the lower percentage $(0.18 \mathrm{mg} / 100 \mathrm{~g}$ of fish).

Calcium content ranged considerably from $112.32-115.6 \mathrm{mg} / 100 \mathrm{~g}$. These results are within the range of fish and seafood reported in FAO/ INFOODS 2013. Phosphorus content ranged from 166.7 to $161.3 \mathrm{mg} / 100 \mathrm{~g}$, consistent with values reported in FAO/INFOODS 2013. The range of magnesium is 25.97 to $24.15 \mathrm{mg} / 100 \mathrm{~g}$, and potassium (207.23 to $205.37 \mathrm{mg} / 100 \mathrm{~g})$ content was consistent with ranges for other fish and seafood reported in FAO/INFOODS 2013.

Iron content varied considerably with a range from 1.85 to $1.78 \mathrm{mg} / 100 \mathrm{~g}$. These results show a greater range in iron content compared to a values reported in the global FAO/INFOODS database on fish and shellfish (excluding molluscs) (FAO/INFOODS 2013). This may be partly attributable to sampling 
variability, methodological differences in analysis of iron content, or may reflect real differences in the accumulation of iron in this species based on differing environmental conditions. The true nature and magnitude of these differences should be further investigated. Overall, the data presented here indicate that this species may contribute significantly to dietary iron intake in Bangladesh which is of high bioavailability as an animal-source food (FAO and WHO 2004). Manganese content ranged from $0.23-0.18 \mathrm{mg} / 100 \mathrm{~g}$ and is higher than results reported in FAO/INFOODS 2013, which may be related to water pollution.

Growth performance of gulsha can survive with the different types of physiochemical parameters such as temperature, $\mathrm{pH}$, and DO. From the experiment it was observed that the length and weight of gulsha fish varied with different feeds. The best growth performance was found in rice bran and spirulina. Rice bran and spirulina has the best proximate composition for human nutritional interest and thus it was found to be the better option to produce healthy fish for human consumption.

\section{LITERATURE CITED}

AKHTERUZZAMAN, M., KOHINOOR, A. H. M., SHAH M.S. and HUSSAIN, M.G. 1991. Observation on the induced breeding of Mystus cavasius. Bangladesh. J. Fish. 14(1-2): 78-82.

AOAC (Association of Official Analytical Chemists) 1995. Official Method of Analysis, 12th edn. Association of Official Analytical Chemists, Washington pp. 832.

BANU, C.P., SUlTANA, S. and SALAMATULLAH, Q. 1991. Mineral content of freshwater fish and meat. Bangladesh. J. Zool. 19(1): 59-63.

BERRA, T.M. 1981. An Atlas of distribution of the freshwater fish families of the World .University.of Nebaraska Press, pp198.

CASTELL, J. D. and TIEWS, K. 1980. Report of the EIFAC, IUNS and ICES working group on the standardization of methodology in fish nutrition research. EIFAC technical paper 36. Hamburg, Federal Republic of Germany, 21-23 March, 1979, 24 pp.

DRESOSIER, N.W. 1977. Element of Food Technology. The Avi. Pub. Co. Inc. pp. 384.

FAO/INFOODS, 2013. FAO/INFOODS Food Composition Database for Biodiversity Version 2.1 BioFoodComp 2.1 Food and Agriculture Organization of the United Nations, Rome, Italy.

FAO/WHO. 2004. Vitamin and Mineral Requirements in Human Nutrition: Report of a Joint FAO/WHO Expert Consultation, 2nd ed. Food and Agriculture Organization of the United Nations, World Health Organization, Geneva, Switzerland. pp. 362.

HOSSAIN, M.A., KOHINOOR, A.H.M. and HUSSAIN, M.G. 1998. Polyculture of gulsha (Mystus cavasius Ham.) with rajpunti (Puntius gonionotus Bleeker) and silver carp (Hypophthylmichthys molitrix Val.) in earthen ponds. Bangladesh. Fish. Res. 2(1): 9-14.

HUNG, L. T., TUAN, N. A. and LAZARD, J. 2001. Effects of frequency and time of feeding on growth and feed utilization in two Asian catfishes, Pangasius bocourti (Sauvage, 1880) and $P$. hypophthalmus (Sauvage, 1878). J. Aquac. Trop. 16(2): 171-184.

HUQ, S. and ALAM, M. 2005. A Handbook on Analyses of Soil, Plant and Water. Eds. (BACER-DU, University of Dhaka, Dhaka, Bangladesh), pp. xxii+246. 
KOHINOOR A.H.M., BEGUM, M. and HUSSAIN, M.G. 2009. Evaluation of different stocking densities of two small indigenous fish, pabda (Ompok pabda) and gulsha (Mystus cavasius) with Indian major carps in polyculture system. Iranian J. Fisheries Sci. 8: 95-100.

KOHINOOR, A.H.M., HOSSAIN, M.A. and HUSSAIN, M.G. 1997. Semi-intensive culture and production cost of pabda (Ompok pabda) with rajpunti (Puntius gonionotus) and mirror carp (Cyprinus carpio var. specularis) in mini ponds. Bangladesh J. Zool. 254(2):129-133.

MEDAWARS, 1945. Physiology of salinity tolerance in tilapia: An update of basic and applied aspects. Aquat. Living Resour. 2: 91-97.

MINOT, J.F. 1990. Developmental rates of Menidia audens with notes on salt tolerance. Trans. Am. Fish. Soc. 100: 603-610.

NIKOLSKY, G.V. 1963. The Ecology of Fishes. Academic press, London, pp. 352.

RAHMAN, A.K.A. 2005. Freshwater Fishes of Bangladesh (2nd edn). Zoological Society of Bangladesh, Department of Zoology, University of Dhaka, Dhaka, 394 pp.

RAHMAN, M.A., BHADRA, A., BEGUM, N. and HUSSAIN, M.G. 1997. Effects of some selected supplemental feeds on the survival and growth of catfish (Clarias batrachus Lin.) fry. Bangladesh J. Fish. Res. 1: 55-58.

RAHMAN , M. A., MAZID, M. A., RAHMAN, M. R., KHAN, M. N., HOSSAIN, M.A. and HUSSAIN, M.G. 2005 Effect of stocking density on survival and growth of critically endangered mahseer, Tor putitora (Hamilton) in nursery ponds. Aquaculture 249: 275-284.

RAHMAN, M.A., ZAHER M., AZIMUDDIN, K.M. YEASMINE, S., KHAN, M.M. and AZIZ, A. 2013. Stocking density effects on growth and production of the threatened silurid catfish, Mystus cavasius (Hamilton) fingerlings in nursery ponds. Aquaculture Res. 44: 1132-1139.

RUBBI, S.F., MUZIBAR, M., KHAN, A.R., JAHAN, S.S., and MAJEDA, B. 1987. Studies on the proximate composition and quality of some commercial species of fresh water fish. Bangladesh J. Sci. Res. 5(1): 1-20.

STANSBY, M.E. 1963. Analytical methods, industrial fishery technology. Reinhold publishing corporation. pp. 359-371. 